\title{
無彩色背景における有彩色と無彩色ラインの弱視者の視認性 STUDY ON THE VISIBILITY OF CHROMATIC AND ACHROMATIC COLOR LINES FOR VISUALLY CHALLENGED PEOPLE
}

\author{
岩田 三千子*, 北 本 裕 之** \\ Michico IWATA and Hiroyuki KITAMOTO
}

\begin{abstract}
Visually challenged people require visual contrasts between targets and backgrounds. The authors performed a laboratory experiment to gauge the visibility of lines under $100 \mathrm{~lx}$ and $1000 \mathrm{~lx}$ illuminance conditions. These lines provide an essential reference point in the walking field for the visually challenged. In this paper the authors show the visibility based on the contrast of lines and backgrounds by chromatic and achromatic color combinations. A total of 43 colors were used as target lines and three achromatic colors were used for the backgrounds. Thus, a total of 129 color combinations were used. Data from this experiment may assist in the designing of walking lines on pavement surfaces which could serve as guidance, warnings and other important or useful directions for visually challenged people.
\end{abstract}

Keywards: visually challenged, amblyopia, luminance ratio, color, barrier free, leading 視覚障害者, 弱視者, 輝度比, 色, バリアフリー, 誘導

\section{1. はじめに}

近年，高齢者や障害者が自立した日常生活や社会生活を送れるよ うに，世界各国で様々な法整備とともに生活環境の整備が進んでい る.わが国でも，駅や空港，バスなどの公共交通機関，および，大 規模なビルや宿泊施設, 飲食店などの利用を円滑にするための,「高 齢者, 障害者等の移動等の円滑化の促進に関する法律（バリアフリ 一新法)」や，各自治体の「福祉のまちづくり条例」が定められて活 動の場が広がっている。

そのような中，視覚障害者の安全な歩行を促すことを目的に，視 覚障害者誘導用ブロック（以下，誘導ブロックという）の設置が求 められている. 誘導用ブロックはJIS で形状が規格化されたことも あり，街路空間における視覚障害者への対応技術として普及してい る. 一方で，その敷設方法や管理方法についての課題も多く，多方 面から誘導ブロックについての研究が行われている。例えば，本田 ら 1) は, 視覚障害者の誘導ブロックのニーズと役割について, 坂口 ら 2) は, 誘導ブロックの設置状況と歩道舗装について, 佐々木ら 3 ) は, 誘導ブロックが自転車利用者や歩行者の走行挙動に及ぼす影響 について, 三上ら 4) は, 敷設状態の触覚的認知性が利用者に及ぼす 影響について, 山田ら 5) は, 曲線歩行時の誘導ブロックの有用性に ついて, さらに, 田中ら ${ }^{6)}$ は, 誘導ブロックのみならずそれ以外の
街路空間における整備手法の可能性を検討している.

視覚障害者というと,「目が見えない人」といった認識をされるこ とが多いが，その中に全盲の人は少なく，光を感じることができ視 機能をある程度有する弱視者の割合が非常に多い。このような弱視 者を対象とした光・視環境と誘導ブロックの関係については，伊藤 ら 7), 坂井ら 8), 坂口ら 9) は, 誘導ブロックの利用状況調查より視 認性確保の重要性を，江齐ら 10）は，夜間街路照明下において誘導 ブロックの視認性が低いことを，田中ら 11) は，夜間の街路歩行時 の空間把握において現誘導ブロックの設置が歩行に有用でないこと を指摘している．また，今泉ら $\left.{ }^{12}\right)$ は，蛍光材料を用いた誘導ブロ ックにより夜間の視認性向上を計る手法を提案し，竹田ら ${ }^{13}$ ) は, 誘 導ブロックと舖装面の色彩の組み合わせについて CG を用いて，識 別可能な輝度比を求め, 高井ら ${ }^{14}$ は, 屋内において一定の照度条件 下で必要な輝度比を明らかにしている。

しかしながら, 未だ誘導ブロックの見えに関する設置基準等では, 「弱視者が認知しや寸いよう」,「明度, 色相, 彩度, 輝度比に配慮」, 「輝度比 2.0 以上確保」などの表現15)に留まっており，有用かつ明 確な数值指標が示されていない. 先に挙げた研究成果でも, 現状の 誘導ブロックを評価することが主たる目的であり，弱視者の見えに ついての数量的なデータが得られているとは言い難い.

\footnotetext{
* 摂南大学理工学部住環境デザイン学科 教授・学博

Prof., Dept. of Living and Environmental Design, Faculty of Science and Engineering,

**大阪市立大学生活科学研究科 客員准教授・学博 Setsunan Univ., Ph. D.

Visiting Assoc. Prof., Graduate School of Human Life Science, Osaka City Univ., Ph. D.
} 
そこで本研究では, 視覚障害者のうち何らかの視覚情報を活用し て日常歩行をし, 歩行時に「誘導ブロックを目で確認したことがあ る」者（以下, 弱視者という）を対象として, 実験室実験により誘 導ブロックに見立てた様々な無彩色および有彩色のラインを無彩色 背景上に置いて, 視認性を検討した.

\section{2. 実験概要}

\section{1 実験装置}

図 1 に実験装置を示す. 装置内には 3 波長型昼光色の蛍光灯が, 被験者の目に入らないところに設置してある. 被験者には開口部の 顎のせ台の上に顎を置いて中を瞀かせ，距離 $1 \mathrm{~m}$ の垂直正面壁にあ る視標を観察させた。 視標直上部には, 照度計の受光部を設置して 照度測定を行って, 視標中心部の照度に換算した。実験装置の内部 は拡散性のマンセル明度（以下，N）５の灰色のペイントで塗装し てあり装置内部の輝度はほぼ一様である.

\section{2 実験視標}

図 2 に, 実験で使用した視標のサイズを示寸.ここで, ライン幅 $75 \mathrm{~mm}$ は, 距離 $1 \mathrm{~m}$ において視角約 $4.5^{\circ}$ の大きさであり, 例えば, 目線高さ $1.5 \mathrm{~m}$ の歩行者が, 幅 $30 \mathrm{~cm}$ の誘導ブロックを約 $4 \mathrm{~m}$ の距 離から視認した大きさに相当する. 通常の健康診断では距離 $5 \mathrm{~m}$ で 視力測定をするが，それよりもやや短い距離を想定している。視標 の背景には無彩色 N9・N5・N3の 3 種類のラシャ紙を使用し, ラ インには JIS 標準色票（日本色彩研究所製マンセル色紙）より, 表 1 に示寸有彩色 35 色と無彩色 8 色を使用した.

有彩色ラインの選定には，まず，色相環を等間隔に 20 分割した 20 色相（色相：5，10）の 20 色を選んだ。このとき, 色を認識す る際には明度の要素が重要であり, YR, Y, GY は低明度になると 橙, 黄, 黄緑の色味の認識ができにくくなることから明度 7 または 8 とし, その他の色は明度 4 または 5 とした。 いずれも彩度は誘導 ブロックの污れなどを考慮して低彩度の 4 とした。 さらに, 色相環 を等間隔に 5 分割した 5 色相（色相：5）のうち, 建築色彩にはあ まり使用されない $5 \mathrm{P}$ を除いた 4 色相 $(5 \mathrm{R} \cdot 5 \mathrm{Y} \cdot 5 \mathrm{G} \cdot 5 \mathrm{~B})$ の彩度 を 2 ずつ変化させた 15 色を加えた

背景とラインとの輝度比 $\mathrm{LR}$ および輝度対比 $\mathrm{C}$ を, それぞれ式 1 ・ 式 2 で定義する.

$\mathrm{LR}=\mathrm{L}_{\mathrm{L}} / \mathrm{LS}_{\mathrm{S}} \quad \cdots \cdot$ 式 1

$\mathrm{L}_{\mathrm{L}}$ : 高い方の輝度 $\left[\mathrm{cd} / \mathrm{m}^{2}\right], \mathrm{L}_{\mathrm{S}}$ : 低い方の輝度 $\left[\mathrm{cd} / \mathrm{m}^{2}\right]$

$\mathrm{C}=(\mathrm{Lb}-\mathrm{Lt}) / \mathrm{Lmax} \quad \cdots \cdot$ 式 2

$\mathrm{Lb}$ : 背景の輝度 $\left[\mathrm{cd} / \mathrm{m}^{2}\right], \mathrm{Lt}:$ ラインの輝度 $\left[\mathrm{cd} / \mathrm{m}^{2}\right]$

Lmax : Lb, Lt の高い方の輝度 $\left[\mathrm{cd} / \mathrm{m}^{2}\right]$

ここで, C が正のとき正対比, 負のとき負対比と呼ぶ. 輝度対比 $\mathrm{C}$ と, 輝度比 LR の関係は, 次の式 $3 \cdot$ 式 4 を用いて算出できる.

$\mathrm{Lb} \geqq \operatorname{Lt} の$ 場合

$$
\mathrm{C}=1-(1 / \mathrm{LR}) \quad \cdots \cdot \text { 式 } 3
$$

$\mathrm{Lb} \leqq \mathrm{Lt} の$ 場合

$$
\mathrm{C}=(1 / \mathrm{LR})-1 \quad \cdots \cdot \text { 式 } 4
$$

式 1 から, 背景とラインとの組み合わせ 129 条件の輝度比を求め た. 表 2 に輝度比の一覧を示寸. なお, 輝度測定にはハンディータ イプの輝度計（MINOLTA 社製 LS110）を用いた。 ただし，ライン の明度值は JIS 標準色票の正確な值であるが，背景のラシャ紙の明
度は概数值である. そのため, 背景とラインが同明度でも輝度比= 1 ではない

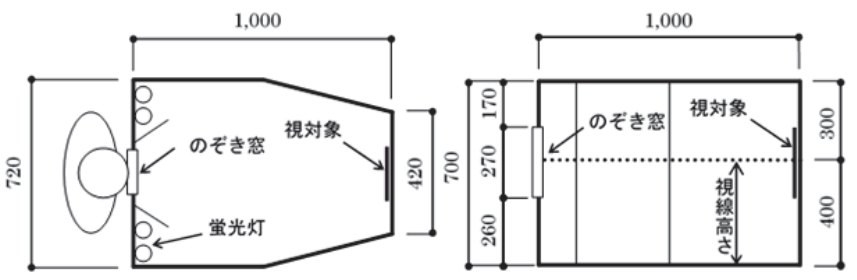

図 1 実験装置 (単位 $\mathrm{mm}$ )

表 1 ラインに使用した有彩色および無彩色

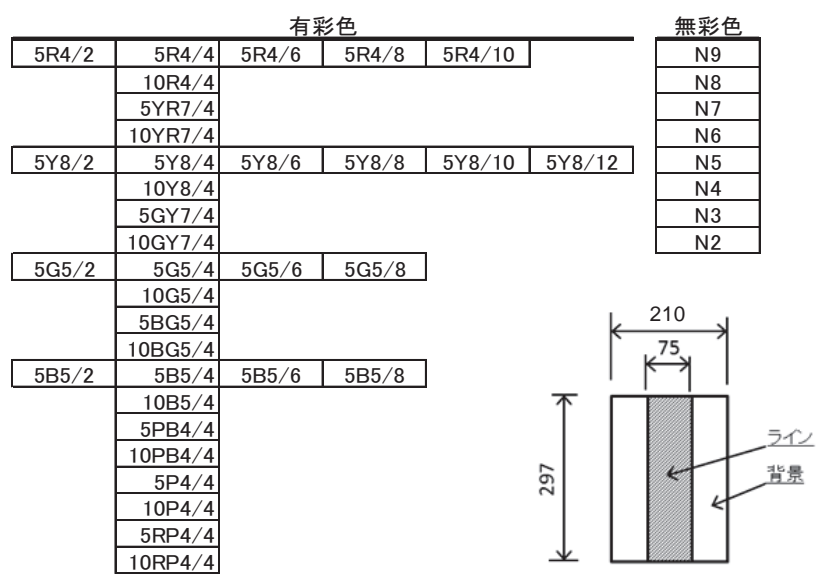

図 2 実験視標 (単位 $m m$ )

\begin{tabular}{|c|c|c|c|c|c|c|c|}
\hline \multirow{2}{*}{ ライン } & \multicolumn{3}{|c|}{ 背景 } & \multirow{2}{*}{ ライン } & \multicolumn{3}{|c|}{ 背景 } \\
\hline & N9 & N5 & N3 & & N9 & N5 & N3 \\
\hline $5 \mathrm{R} 4 / 10$ & 5.71 & 1.23 & 2.25 & $5 \mathrm{BG} 5 / 4$ & 3.85 & 1.17 & 3.23 \\
\hline $5 \mathrm{R} 4 / 8$ & 5.71 & 1.27 & 2.13 & $10 \mathrm{BG} 5 / 4$ & 4.26 & 1.08 & 2.99 \\
\hline $5 \mathrm{R} 4 / 6$ & 5.71 & 1.29 & 2.15 & 5 B5/8 & 4.08 & 1.12 & 3.08 \\
\hline $5 \mathrm{R} 4 / 4$ & 6.06 & 1.36 & 2.04 & $5 \mathrm{~B} 5 / 6$ & 4.08 & 1.11 & 3.08 \\
\hline $5 \mathrm{R} 4 / 2$ & 6.06 & 1.36 & 2.04 & $5 \mathrm{~B} 5 / 4$ & 4.26 & 1.05 & 2.90 \\
\hline $10 \mathrm{R} 4 / 4$ & 5.88 & 1.29 & 2.15 & $5 \mathrm{~B} 5 / 2$ & 4.35 & 1.02 & 2.86 \\
\hline $5 Y R 7 / 4$ & 2.06 & 2.20 & 6.06 & $10 \mathrm{~B} 5 / 4$ & 4.00 & 1.12 & 3.13 \\
\hline $10 Y R 7 / 4$ & 1.98 & 2.27 & 6.45 & $5 \mathrm{~PB} 4 / 4$ & 5.56 & 1.23 & 2.27 \\
\hline $5 Y 8 / 12$ & 1.35 & 3.33 & 9.52 & $10 \mathrm{~PB} 4 / 4$ & 6.90 & 1.52 & 1.85 \\
\hline $5 Y 8 / 10$ & 1.38 & 3.23 & 9.09 & $5 \mathrm{P} 4 / 4$ & 5.88 & 1.32 & 2.11 \\
\hline $5 Y 8 / 8$ & 1.39 & 3.23 & 9.09 & $10 \mathrm{P} 4 / 4$ & 6.67 & 1.48 & 1.89 \\
\hline $5 Y 8 / 6$ & 1.46 & 3.13 & 8.70 & $5 \mathrm{RP} 4 / 4$ & 5.56 & 1.23 & 2.27 \\
\hline $5 Y 8 / 4$ & 1.47 & 3.03 & 8.70 & 10RP4/4 & 7.14 & 1.60 & 1.75 \\
\hline $5 Y 8 / 2$ & 1.49 & 3.03 & 8.33 & N9 & 1.09 & 4.08 & 11.11 \\
\hline $10 Y 8 / 4$ & 1.45 & 3.13 & 8.70 & N8 & 1.49 & 3.03 & 8.33 \\
\hline $5 \mathrm{GY} 7 / 4$ & 2.02 & 2.25 & 6.25 & N7 & 2.02 & 2.22 & 6.25 \\
\hline $10 G Y 7 / 4$ & 2.11 & 2.13 & 5.88 & $\mathrm{~N} 6$ & 2.70 & 1.67 & 4.65 \\
\hline $5 \mathrm{G} 5 / 8$ & 3.85 & 1.18 & 3.28 & N5 & 4.08 & 1.12 & 3.13 \\
\hline $5 \mathrm{G} 5 / 6$ & 4.08 & 1.12 & 3.13 & $\mathrm{~N} 4$ & 6.45 & 1.43 & 1.94 \\
\hline $5 G 5 / 4$ & 4.08 & 1.11 & 3.08 & N3 & 11.8 & 2.63 & 1.05 \\
\hline $5 \mathrm{G} 5 / 2$ & 4.44 & 1.03 & 2.82 & $\mathrm{~N} 2$ & 25.0 & 5.88 & 2.08 \\
\hline $10 \mathrm{G} 5 / 4$ & 4.44 & 1.04 & 2.86 & & & & \\
\hline
\end{tabular}

表 2 背景とラインの輝度比

\section{3 実験方法}

図 1 の実験装置を暗室（摂南大学 8 号館 3 階）に設置した. 被験 者は実験前に暗室内で 5 分間の暗順応を行い, 目の順応状態を統一 させた．視標面照度は，JIS 照度基準にある日常的な屋内生活環境 の明るさを想定し, 商業施設の廊下や地下歩行者通路などに採用さ れている数值を丸めた $1001 \mathrm{x}$ と, その 10 倍で, 屋内環境としては 十分に明るい 1000lx の 2 通りとした. 100lx, 1000lx の照度条件の 順に各 3 分程度実験条件に明順応させた。 その後, 実験視標をラン ダムに提示し, ラインの視認性について「4：わかりやすい」,「3： まあまあわかる」,「2:わかりにくい」,「1:わからない」の 4 段階 の点数を口頭で回答させた。 


\section{4 被験者}

被験者として単独歩行が可能な 43〜81 才の弱視者 31 名（男 15 名, 女 16 名) が参加した. 視覚障害者は加齢とともに増加する傾 向があり，ここでは 20〜30才代の若年者層を含んでいない. 被験 者の主たる疾病の箇所に基づいて, 網膜系, 光学系, その他の 3 分 類で表し, 属性一覧を表 3 に示寸. 両眼の視力の和注) が 0.1 未満の 者が 22 名で, そのうち光を感じることはできるがランドルト環の 開きを判別するといったような細かい視作業ができない者（両眼と もに指数弁, 手動弁, 光覚弁) は 6 名であった. また, 31 名の内, 14 名が白杖を補助具として使用していた。

被験者の年齢と視力の関係について, 年齢を横軸に左右の良い方 の視力を縦軸にとって図 3 に示寸. 年齢と視力には相関がないこと が分かる. また, 視標面照度 $1000 \mathrm{~lx}$ における背景 N9 の場合を例と して, 左右の良い方の視力と評価值との関係を図 4 に示寸. これよ り, 評価は視力に関係なくばらついていることが分かる. これは他 の条件も同様の傾向であった. 視力の数值で表せない指数弁, 手動 弁, 光覚弁の 6 名は遠距離での視認は困難と考えられるが, 半数は 白杖を使用せず，歩行上，他と比べて明確な違いはない．

\section{表 3 被験者属性一覧}

\begin{tabular}{|c|c|c|c|c|c|c|c|c|c|c|c|}
\hline \multirow{2}{*}{ 番号 } & \multirow{2}{*}{\multicolumn{2}{|c|}{ 性別年齢 }} & \multirow[b]{2}{*}{ 疾病名 } & \multirow{2}{*}{ 分類 } & \multirow{2}{*}{$\begin{array}{l}\text { 發症 } \\
\text { 時期 }\end{array}$} & \multicolumn{2}{|c|}{ 視力 } & \multirow{2}{*}{\begin{tabular}{|l} 
障害者 \\
等級
\end{tabular}} & \multirow{2}{*}{\begin{tabular}{|l|} 
視野 \\
欠損
\end{tabular}} & \multirow{2}{*}{\begin{tabular}{|l|} 
色賞 \\
常
\end{tabular}} & \multirow{2}{*}{ 白杖 } \\
\hline & & & & & & 右 & 左 & & & & \\
\hline 1 & 男 & 64 & 網膜色素変性症 & \multirow{9}{*}{$\begin{array}{l}\text { 網 } \\
\text { 膜 } \\
\text { 系 }\end{array}$} & 51 & 手動弁 & 指数弁 & 1 & 0 & & 0 \\
\hline 2 & 女 & & $\begin{array}{l}\text { 網膜色素変性症 } \\
\end{array}$ & & 55 & 0.01 & 指数弁 & $\frac{1}{1}$ & 0 & $\mathrm{O}$ & 0 \\
\hline 3 & 女 & 52 & 網膜色素変性症 & & 34 & 0 & 0.02 & 2 & 0 & & \\
\hline 4 & 女 & 59 & 網膜はく離 & & 36 & 0 & 0.02 & 2 & 0 & & \\
\hline 5 & 女 & 63 & 網膜色素変性症 & & 52 & 0.03 & 0 & 2 & 0 & & \\
\hline 6 & 女 & 72 & 網膜はく<離 & & 56 & 0.03 & 0.03 & 3 & & & \\
\hline 7 & 鱼 & 56 & 強度遠視·網罔はく離 & & 46 & 0 & 0.08 & 3 & & & \\
\hline 8 & 女 & 60 & 網膜色素変性·緑内障 & & 58 & 0 & 0.1 & 4 & 0 & & 0 \\
\hline $\begin{array}{l}0 \\
9\end{array}$ & 莮 & 48 & 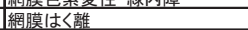 & & $\frac{00}{14}$ & 0.1 & 光賞弁 & $\frac{4}{4}$ & & & 0 \\
\hline 10 & 女 & 68 & 白内内障 & \multirow{7}{*}{$\begin{array}{l}\text { 光 } \\
\text { 学 } \\
\text { 系 }\end{array}$} & 先天性 & 手動弁 & 光賞弁 & 1 & & & \\
\hline 11 & 男 & 63 & 角膜白斑 & & 15 & 0 & \begin{tabular}{|l|l|}
0.02 \\
\end{tabular} & 2 & & & 0 \\
\hline$\frac{11}{12}$ & 莮 & $\begin{array}{ll}03 \\
63\end{array}$ & 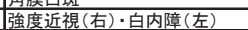 & & 先天性 & 0.06 & \begin{tabular}{|l|l|} 
光覚弁 \\
\end{tabular} & $\frac{2}{3}$ & 0 & 0 & 0 \\
\hline 13 & 男 & 56 & 水晶体脱臼症 & & 先天性 & 0.1 & 0.04 & 5 & 0 & & \\
\hline 14 & 男 & 70 & 強度近視·網膜はく離·白内障 & & 33 & 0.1 & 0.1 & 5 & & & \\
\hline 15 & 女 & 55 & \begin{tabular}{|l} 
結膜炎 \\
\end{tabular} & & 先天性 & 0.1 & 0.1 & 5 & & & \\
\hline 16 & 女 & 71 & ぶジ゙う膜炎・白内障 & & 48 & \begin{tabular}{|l|l|}
0 & 0 \\
\end{tabular} & 0.6 & 6 & 0 & & \\
\hline 17 & 劎 & 68 & 不明 & \multirow{15}{*}{$\begin{array}{l}\text { そ) } \\
\text { の } \\
\text { 他 }\end{array}$} & 先天性 & 手動弁 & 手動弁 & $\frac{0}{1}$ & 0 & $\bar{O}$ & \\
\hline 18 & 男 & $\begin{array}{ll}63 \\
63\end{array}$ & 熟成しん瘆變 & & 57 & 手動弁 & 手動弁 & $\frac{1}{1}$ & 0 & 0 & 0 \\
\hline 19 & 女 & 54 & 小眼球症·ぶ・゙゙う膜欠損症 & & 先天性 & 手動弁 & 手動弁 & 1 & & & \\
\hline 20 & 鱼 & 57 & 交通事故 & & 14 & 指数弁 & 指数弁 & 1 & 0 & $\mathrm{O}$ & 0 \\
\hline 21 & 女 & 58 & 不明 & & 先天性 & 0 & 0.01 & 1 & & & 0 \\
\hline 22 & 劎 & 49 & 視神経萎縮 & & 13 & 0 & 0.01 & 1 & $\mathrm{O}$ & & \\
\hline$\frac{24}{23}$ & 女 & 45 & 小眼球症 & & 先天性 & 0 & 0.02 & $\frac{1}{2}$ & 0 & & 0 \\
\hline 24 & 女 & 55 & 強度近視 & & 先天性 & 0.02 & 0 & 2 & & & \\
\hline 25 & 釜 & 53 & 势强度近視 & & 先天性 & 0.02 & 0.02 & $\frac{2}{2}$ & & & 0 \\
\hline 26 & 男 & 62 & 無眼球 (右)・小眼球症 (左) & & 先天性 & 0 & 0.03 & 2 & 0 & & 0 \\
\hline 27 & 男 & 81 & 視神経菱縮·緑内障 & & 15 & 0.03 & 0 & 2 & & & 0 \\
\hline 28 & 女 & 57 & 視神経菱縮·緑内障 & & 42 & 0.04 & 0 & 2 & & & 0 \\
\hline 29 & 女 & 54 & 小眼球症·眽絡膜欠損 & & 先天性 & 0.06 & 0 & 3 & & & \\
\hline 30 & 脸 & 43 & 強度近視 & & 先天性 & 0.1 & 0.3 & $\frac{3}{6}$ & & & \\
\hline 31 & 女 & 52 & 視神経萎縮·緑内障 & & 42 & 0 & 0.4 & 6 & & & \\
\hline
\end{tabular}

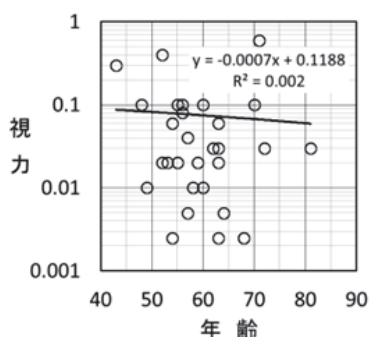

図 3 年齢と視力の関係

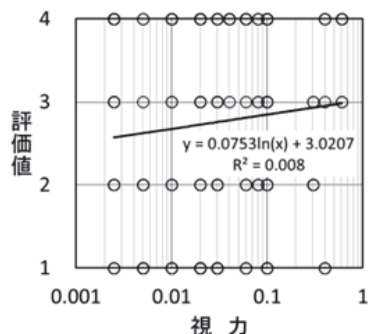

図 4 視カと評価値の関係

\section{3. 実験結果}

\section{1 疾病分類および色覚による検討}

被験者の疾病分類別に, 無彩色ラインの照度別, 背景別の評価平 均值と標準偏差を図 5 に示す. いずれの条件も, 最も評価平均值が 低いのは網膜系であるが, 疾病分類間の分散分析結果では, 1000lx の背景 N9 を除いて $5 \%$ 水準で有意差が認められなかった。
次に，5名の色覚異常「あり」と，26 名の「なし」のグループ別 に, 全有彩色ラインの評価平均值および有意水準 $5 \%$ での分散分析 結果を図 6 に示寸，有彩色ラインの評価平均值は，照度 100lx 背景 N3の条件を除いて, 色覚異常ありの方が有意に低いことがわかる. 両者の評価平均值の差は, 1001x 背景 N5 の 0.47 が最大である. よっ て, 3.3 節の有彩色ラインの視認性については, 色覚異常ありの被 験者 5 名を除外して検討することとする.

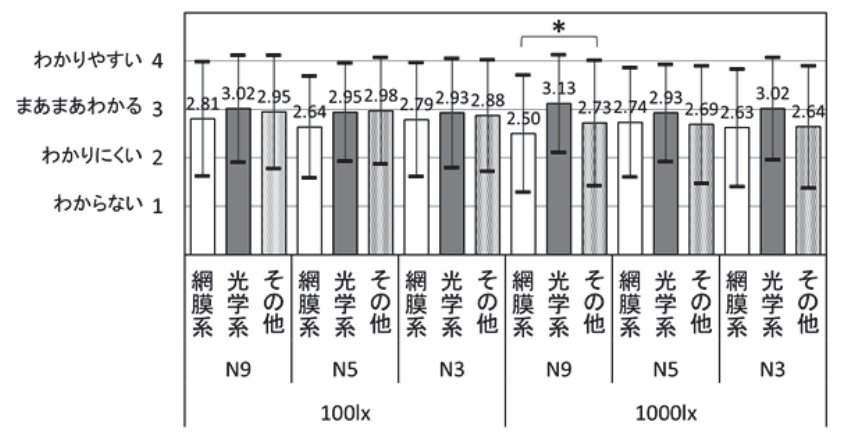

図 5 無彩色ラインの疾病分類別評価平均値

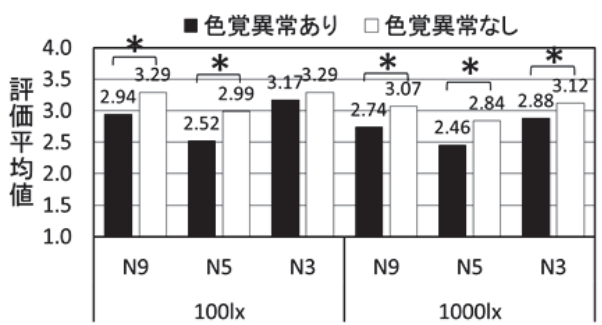

図 6 色覚異常あり・なし別有彩色ラインの評価平均値と有意差

\section{2 無彩色ラインの視認性}

\section{2.1 ラインの明度と肯定回答率の関係}

照度別, 背景別に, 無彩色ラインの回答率を図 7 に示寸。また, 4 段階評価のうち「4：わかりやすい」と「3：まあまあわかる」の 合計回答割合（以下，肯定回答率という）を折れ線グラフで示す. これより，概して背景とラインの明度差が大きいほど肯定回答率が 高いことが分かる. 1001x，1000lx ともに，背景 N9 では明度差 3 以上，背景 N5 および N 3 では概ね明度差 2 以上で，肯定回答率が $50 \%$ 超える。 また， $100 \mathrm{~lx}$ と $1000 \mathrm{~lx}$ とを比較すると，背景とライ ンの明度差が大きい場合には肯定回答率は $100 \mathrm{~lx}$ の方が高いが，小 さい場合には逆転して概ね $1000 \mathrm{~lx}$ の方が高いことが分かる.

\section{2.2 輝度対比と肯定回答率の関係}

正対比と負対比の別に, 背景とラインの輝度対比と肯定回答率と の関係を図 8 に，回帰式を表 4 に示す。ただし，図中の回帰直線は 実験の範囲を実線で，それ以外は回帰直線の $\mathrm{y}$ 軸（肯定回答率）の 切片 $\mathrm{b}$ を 0 以下として回帰し点線で示している.

図 8 より, 肯定回答率 $80 \%$ おび $50 \%$ を得るための輝度対比に言 及すると, $80 \%$ にいては, $1001 \mathrm{x}$ の正対比では 0.8 以上, 負対比 では-0.7 以下, $10001 \mathrm{x}$ の正対比では 0.9 以上，負対比では -0.8 以下である. $50 \%$ にいては，1001x の正対比では 0.5 以上，負対 比では- 0.5 以下, $1000 \mathrm{~lx}$ の正対比では 0.6 以上，負対比では -0.5 以下である. また, 正対比では輝度対比 0.33 , 負対比では輝度対比 -0.29 で $100 \mathrm{~lx}$ と $1000 \mathrm{~lx}$ との肯定回答率の逆転が生じていること が分かる. 
回帰式の決定係数については, 正対比の $100 \mathrm{~lx}$ で 0.93, 1000lx で 0.90 と正の相関が高く, 傾きは $1001 \mathrm{x}$ が 1.18, 1000lx が 1.00 である. また，負対比の決定係数は $1001 \mathrm{x}$ で $0.69,10001 \mathrm{x}$ で 0.55 と相関が高く, 傾きはそれぞれ-1.21, - 0.97 である. 照度別には, 正対比と負対比の傾きの絶対值はほぼ等しいことがわかる.さらに, 輝度対比の絶対值が大きくなるほど, 1001x と 1000lx の肯定回答率 の差が大きくなることが分かる.

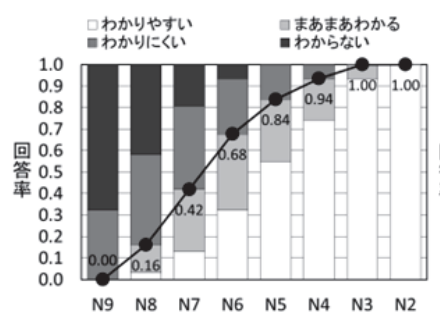

ライン

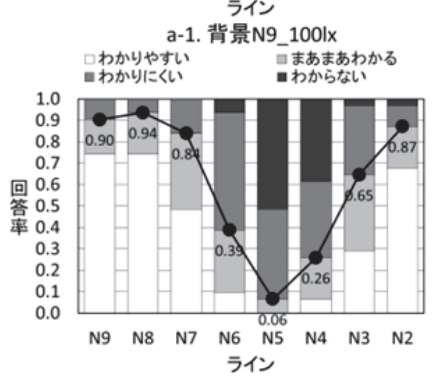

b-1. 背景N5_1001x

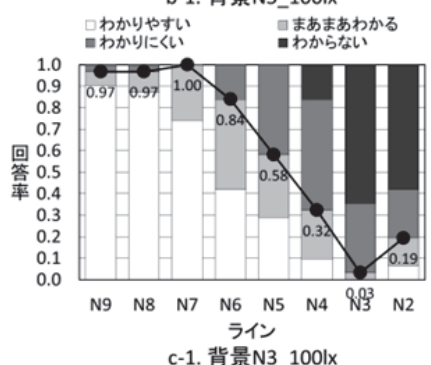

c-1. 背景N3_1001x

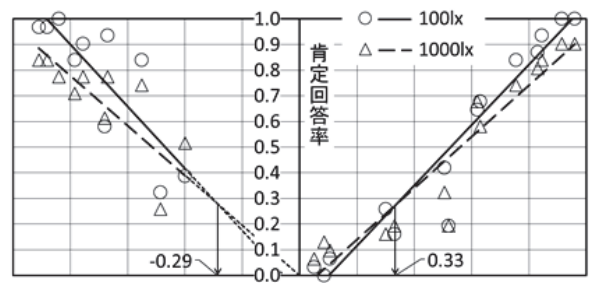

$\begin{array}{lllllllllll}-1.0 & -0.8 & -0.6 & -0.4 & -0.2 & 0.0 & 0.2 & 0.4 & 0.6 & 0.8 & 1.0 \\ \text { 輝度対比 } & & & & & & & \end{array}$

図 8 無彩色ラインの輝度対比と肯定回答率の関係

表 4 輝度対比による無彩色ラインの肯定回答率回帰式

\begin{tabular}{c|c|c|c|c|c|c}
\multicolumn{4}{c}{$\mathrm{y}=\mathrm{a} \cdot \mathrm{x}+\mathrm{b}$} & \multicolumn{3}{c|}{$\mathrm{y}$ : 肯定回答率 $\mathrm{x}$ : 輝度対比 } \\
\hline \multirow{2}{*}{ 対比 } & \multicolumn{3}{|c|}{$1001 \mathrm{x}$} & \multicolumn{3}{|c}{$10001 \mathrm{x}$} \\
\cline { 2 - 7 } & $\mathrm{a}$ & $\mathrm{b}$ & $\mathrm{R}^{2}$ & $\mathrm{a}$ & $\mathrm{b}$ & $\mathrm{R}^{2}$ \\
\hline 正 & 1.18 & -0.12 & 0.93 & 1.00 & -0.06 & 0.90 \\
\hline 負 & -1.21 & -0.07 & 0.69 & -0.97 & 0.00 & 0.55 \\
\hline
\end{tabular}

\section{2.3 輝度比と肯定回答率の関係}

表 4 の各回帰式の輝度対比 $\mathrm{x}$ に式 3 , 式 4 を代入し, 寸なわち, 次の式 5 , 式 6 で輝度比と肯定回答率 $\mathrm{y}$ との関係を求めることがで きる.

正対比 : $\mathrm{y}=\mathrm{a} \cdot(1-(1 / \mathrm{LR}))+\mathrm{b} \cdot \cdots$ 式 5

負対比： $\mathrm{y}=\mathrm{a} \cdot((1 / \mathrm{LR})-1)+\mathrm{b} \cdot \cdots$ 式 6 $\mathrm{y}$ : 肯定回答率, LR : 輝度比
これより, 式 5 , 式 6 から輝度比と肯定回答率との関係を求め, 図 9 に示寸. 図 9 より, 肯定回答率 $80 \%$ および $50 \%$ を得るための輝 度比に言及すると， $80 \%$ にいては，1001x の正対比では輝度比 4.6 以上, 負対比では 3.5 以上, $1000 \mathrm{~lx}$ の正対比では 7.1 以上, 負対比 では 5.6 以上であることが分かる。また，50\%については，1001x の正対比では輝度比 2.1 以上, 負対比では 1.9 以上, $10001 \mathrm{x}$ の正対 比では 2.3 以上，負対比では 2.1 以上であることが分かる. 前述 （3.2.1 節，3.2.2 節）のように, 同じ輝度比では, 負対比が正対比 より肯定回答率が高いことが分かる.さらに, 1001x と 1000lx との 肯定回答率の逆転が, 正対比は輝度比 1.50 , 負対比は輝度比 1.40 で起こることが分かる.

次に, 肯定回答率の実験值と, 式 5 , 式 6 から得られる計算値と の関係を図 10 に, 各回帰式を表 5 に示寸.

正対比の回帰式の決定係数は, $1001 \mathrm{x}$ で $0.93,10001 \mathrm{x}$ で 0.90 と 高く，その傾きはそれぞれ，0.93，0.90で，ほぼ 1 対 1 の比例関係 にあるといえる.一方，負対比の決定係数は，100lx で 0.69, 1000lx で 0.58 ，傾きはそれぞれ $0.70 ， 0.71$ である.

従って, 式 5 , 式 6 を用いて算出した計算值は, 負対比ではやや 誤差はあるものの，おおよそ実用に耐えうるものといえる.

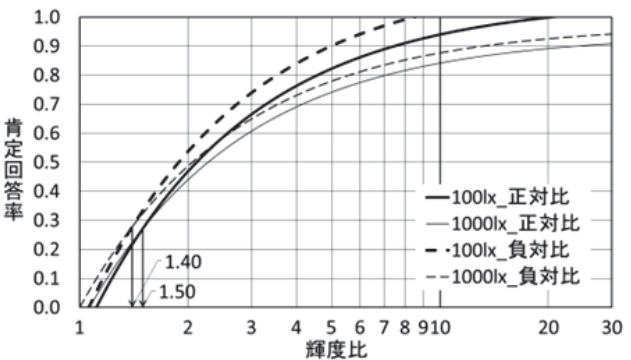

図 9 無彩色ラインの輝度比と肯定回答率の関係

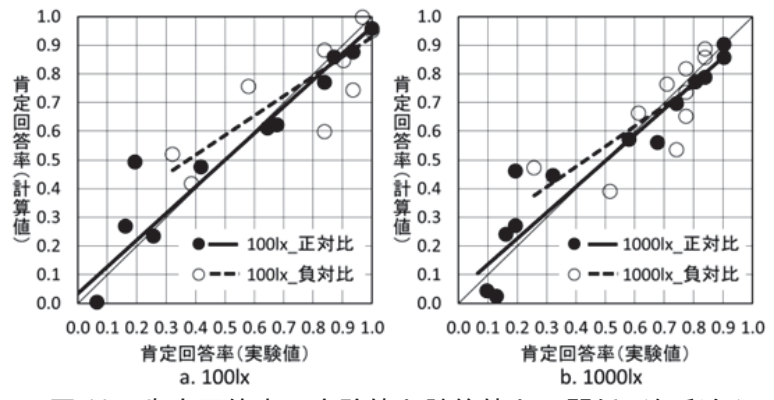

図 10 肯定回答率の実験値と計算值との関係（無彩色） 表 5 実験値と計算值の回帰式 (無彩色)

\begin{tabular}{c|c|c|c|c|c|c}
\multicolumn{4}{c}{$y=a \cdot x+b$} & \multicolumn{3}{c}{$10001 x$} \\
\hline \multirow{2}{*}{ 対比 } & \multicolumn{3}{c|}{$1001 \mathrm{x}$} & 算値 $\mathrm{x}$ : 実験値 \\
\cline { 2 - 7 } & $\mathrm{a}$ & $\mathrm{b}$ & $\mathrm{R}^{2}$ & $\mathrm{a}$ & $\mathrm{b}$ & $\mathrm{R}^{2}$ \\
\hline 正 & 0.93 & 0.03 & 0.93 & 0.90 & 0.05 & 0.90 \\
\hline 負 & 0.69 & 0.24 & 0.69 & 0.71 & 0.19 & 0.58 \\
\hline
\end{tabular}

\section{3 有彩色ラインの視認性}

有彩色ラインは, 色相, 背景との明度差 (輝度比), および, 彩度 差が視認性に影響を与え, 中でも輝度比の影響は大きい. よって, これらを変数として，以下に視認性（肯定回答率）との関係を検討 し, 照度別・色相別に彩度と輝度比より肯定回答率を得るための, 実用的かつ簡便な回帰式を提示する。

\section{3.1 同彩度（彩度 4） 20 色と肯定回答率との関係}

彩度 4 の 20 色相の肯定回答率を図 11 に示す. 図 11 では右回り に $5 \mathrm{YR} \sim 10 \mathrm{GY}$ が明度 7 または 8 であり，5G〜10R が明度 4 また 
は 5 である. よって, 肯定回答率は明度差の影響を受けて, 両照度 とも背景 N9 では $5 \mathrm{G} \sim 10 \mathrm{R}$ の低明度, 背景 N3 では $5 \mathrm{YR} \sim 10 \mathrm{GY}$ の 高明度の肯定回答率が高いことが分かる.

また，無彩色ラインの視認性と同様に, 1001x の方が 1000lx より も肯定回答率が高く, 特に 1001x では, 背景 N9 の $5 \mathrm{G} 5$ および $5 \mathrm{BG} 5 \sim 10 \mathrm{R} 4$, 背景 N5 の 5YR〜10GY, 背景 N3 の 5YR〜 5B5 の 30 通りが $80 \%$ 以上である.

一方， 1000lx では，背景 N9 の 5B5 および 5PB4〜10R4, 背景 N5 の $5 \mathrm{Y} 8$ と $5 \mathrm{Y} 4$, 背景 N3 の 5YR〜 10GY7 の 17 通りが肯定回答 率 $80 \%$ 以上である。
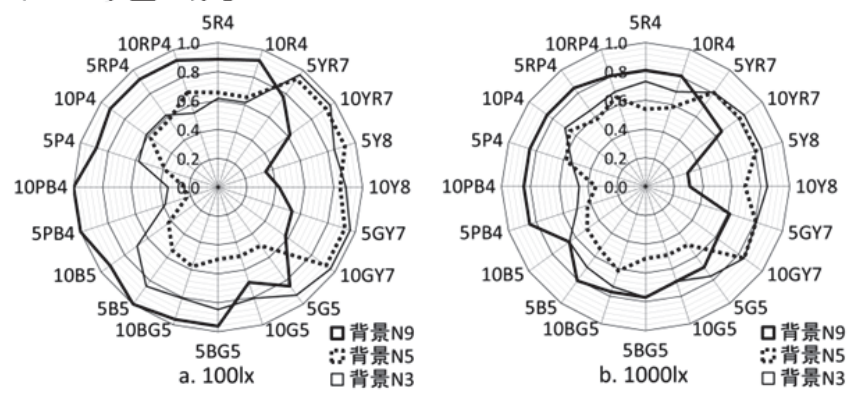

図 11 彩度 4 の 20 色相の肯定回答率

\section{3.2 彩度と肯定回答率の関係}

彩度の段階を有する $5 \mathrm{R} 4 \cdot 5 \mathrm{Y} 8$ ・ 5G5 ・5B5 の 4 色相の 19 色に ついて, 肯定回答率と彩度との関係を色相別に図 12 に示寸. 同明 度の無彩色ラインについても図中の彩度 0 の位置にプロットする (図中の $\triangle \mathrm{N}^{-}$). また, 図中の凡例の濃淡は背景の違いを表している. これより，4色相の回帰式を背景別に表 6 に示す.

図 12 より, 概ね彩度が高くなると肯定回答率が高くなる傾向が 認められる.ただし, 背景との明度差が大きいものは彩度が低くて も肯定回答率が高く, 彩度の効果は得られにくい, 一方, 彩度が高 くても肯定回答率が顕著に低いものとして, 背景 N9 の $5 \mathrm{Y} 8$ が上げ られ, $1001 \mathrm{x}$ では彩度 8 以上, $10001 \mathrm{x}$ では彩度 10 以上でないと肯 定回答率が $50 \%$ 以上にならない。

\subsection{3 彩度および輝度比と肯定回答率との関係}

表 6 の回帰式の傾き $\mathrm{a}$, および, 定数項 $\mathrm{b}$ に着目し, 輝度比との 関係を求める. 照度別・色相別に, 輝度比と傾き $\mathrm{a}$ との関係を図 13 に, それぞれの回帰式を表 7 に示寸. また, 輝度比と定数項 $\mathrm{b}$ との 関係を図 14 に, それぞれの回帰式を表 8 に示す。ここで用いる輝 度比は, 表 2 の輝度比の実測值である.

図 13 および表 7 から, 輝度比と傾き a との関係については, $5 \mathrm{Y} 8$ の傾きが 1001x, 1000lx ともに, 他と比べて緩やかであることが特 徵的である. それぞれの回帰式の決定係数は, $1001 \mathrm{x}$ の $5 \mathrm{Y} 8$ で 0.59 とやや低いが, それ以外では 0.93 以上と高い值である.

図 14 および表 8 から, 輝度比と定数項 $\mathrm{b}$ との関係については, 色相の違いによる大きな差異はない. 決定係数は, 1001x の 5 Y8 で 0.67 とやや低いが，それ以外では 0.82 以上と高い值である.

ここで, 表 6 の回帰式に, 表 7 および表 8 の回帰式を代入すると 次式となる.

$\mathrm{y}=\left(\mathrm{a}_{1} \cdot \log _{\mathrm{e}} \mathrm{x}+\mathrm{b}_{1}\right) \cdot \mathrm{xc}+\mathrm{a}_{2} \cdot \log _{\mathrm{e}} \mathrm{x}+\mathrm{b}_{2} \quad \cdots \quad$ 式 7

$\mathrm{y}$ : 肯定回答率, $\mathrm{x}$ : 輝度比, $\mathrm{xc}$ : 彩度,

$\mathrm{a}_{1}$ : 表 7 の回帰式の傾き, $\mathrm{b}_{1}$ : 表 7 の回帰式の定数項,

$\mathrm{a}_{2}$ : 表 8 の回帰式の傾き, $\mathrm{b}_{2}$ : 表 8 の回帰式の定数項
式 7 の精度を検証するため, 色相別に, 肯定回答率の実験值と, 式 7 から得られる計算值との関係を図 15 に，その回帰式を表 9 に 示す. 各回帰式の傾きは, $5 \mathrm{Y} 8$ は 1001x で $0.68,10001 \mathrm{x}$ で 0.77 で あるが，他は $0.86 〜 0.95$ の範囲に収まり，それぞれの決定係数は 0.69 以上である. 従って, 色相により差異はあるものの, 実験值と 計算值は高い比例関倸にあるといえる.
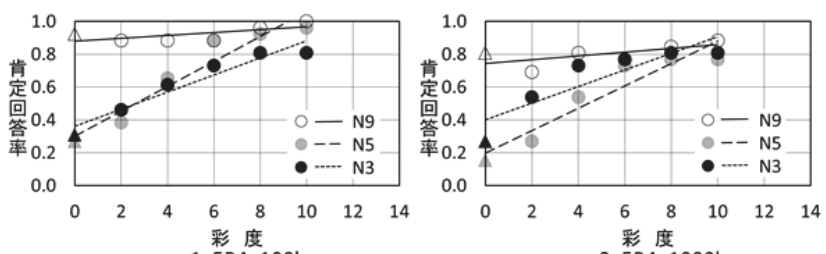
a-1. 5R4_1001x
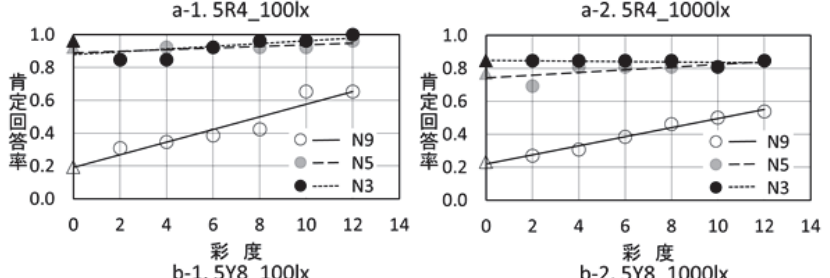

b-1.5Y8_100lx
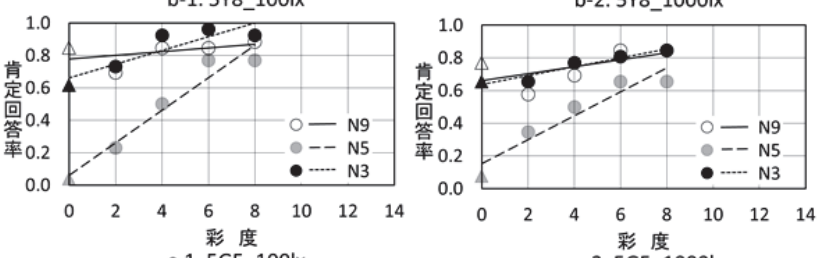
c-1. 5G5_100

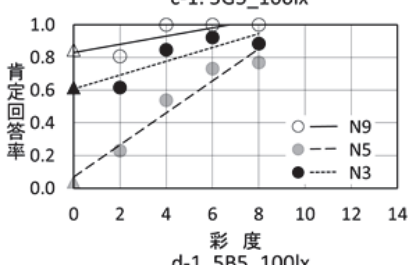
c-2.5G5_10001x

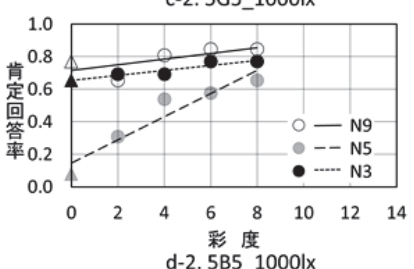

図 12 有彩色ラインの肯定回答率と彩度の関係

表 6 有彩色ラインの肯定回答率と彩度の回帰式

\begin{tabular}{|c|c|c|c|c|c|c|c|}
\hline & \multirow{3}{*}{ 背景 } & \multicolumn{3}{|c|}{$y=a \cdot x c+b$} & \multicolumn{3}{|c|}{ y: 肯定回答率 $x \mathrm{c}$ : 彩度 } \\
\hline \multirow{2}{*}{ ライン } & & & $001 x$ & & & $0001 \mathrm{x}$ & \\
\hline & & $\mathrm{a}$ & $\mathrm{b}$ & $\mathrm{R}$ & $\mathrm{a}$ & $\mathrm{b}$ & $\mathrm{R}$ \\
\hline \multirow{3}{*}{$5 \mathrm{R} 4$} & N9 & 0.009 & 0.88 & 0.68 & 0.012 & 0.74 & 0.65 \\
\hline & N5 & 0.076 & 0.30 & 0.96 & 0.068 & 0.20 & 0.94 \\
\hline & N3 & 0.052 & 0.36 & 0.96 & 0.051 & 0.40 & 0.89 \\
\hline \multirow{3}{*}{$5 Y 8$} & N9 & 0.038 & 0.19 & 0.96 & 0.027 & 0.22 & 0.99 \\
\hline & N5 & 0.005 & 0.89 & 0.60 & 0.008 & 0.74 & 0.73 \\
\hline & N3 & 0.008 & 0.88 & 0.59 & -0.001 & 0.85 & -0.41 \\
\hline \multirow{3}{*}{$5 \mathrm{G} 5$} & N9 & 0.012 & 0.78 & 0.49 & 0.021 & 0.66 & 0.59 \\
\hline & N5 & 0.100 & 0.06 & 0.97 & 0.073 & 0.15 & 0.95 \\
\hline & N3 & 0.042 & 0.66 & 0.89 & 0.027 & 0.64 & 0.96 \\
\hline \multirow{3}{*}{$5 \mathrm{~B} 5$} & N9 & 0.025 & 0.83 & 0.83 & 0.017 & 0.72 & 0.69 \\
\hline & N5 & 0.098 & 0.07 & 0.97 & 0.071 & 0.15 & 0.95 \\
\hline & N3 & 0.042 & 0.61 & 0.89 & 0.015 & 0.65 & 0.94 \\
\hline
\end{tabular}
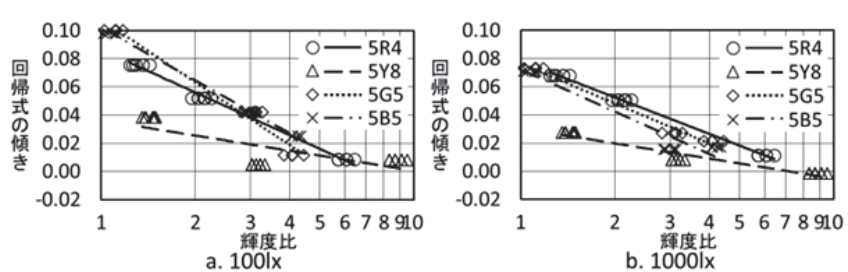

図 13 輝度比と表 6 の各回帰式の傾き $\mathrm{a}$ との関係

表 7 輝度比亡傾き a $の$ 回帰式 $a=a_{1} \cdot \operatorname{loge} x+b_{1}$

\begin{tabular}{c|c|c|c|c|c|c}
\multicolumn{7}{c}{$\mathrm{a}$ : 有彩色ライン回帰式の傾き $\mathrm{x}$ : 輝度比 } \\
\hline \multirow{2}{*}{ ライン } & \multicolumn{3}{c|}{$1001 \mathrm{x}$} & \multicolumn{3}{c}{$10001 \mathrm{x}$} \\
\cline { 2 - 7 } & $\mathrm{a}_{1}$ & $\mathrm{~b}_{1}$ & $\mathrm{R}^{2}$ & $\mathrm{a}_{1}$ & $\mathrm{~b}_{1}$ & $\mathrm{R}^{2}$ \\
\hline 5R4 & -0.044 & 0.087 & 1.00 & -0.038 & 0.079 & 1.00 \\
\hline 5Y8 & -0.016 & 0.036 & 0.59 & -0.016 & 0.031 & 0.93 \\
\hline 5G5 & -0.065 & 0.108 & 0.98 & -0.041 & 0.077 & 0.99 \\
\hline 5B5 & -0.054 & 0.102 & 1.00 & -0.043 & 0.072 & 0.93 \\
\hline
\end{tabular}



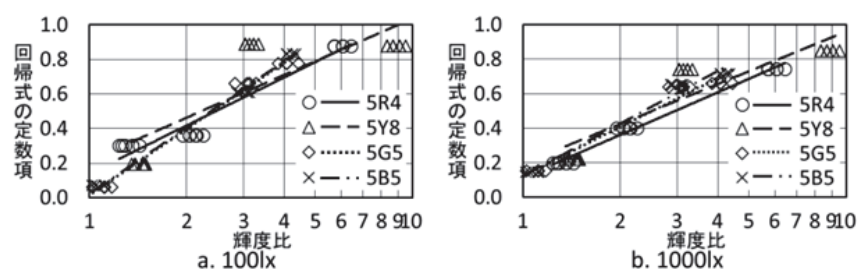

図 14 輝度比と表 6 の各回帰式の定数項 b との関係

表 8 輝度比と定数項 $\mathrm{b}$ の回帰式 $b=a_{2} \cdot \operatorname{loge} x+b_{2}$

\begin{tabular}{c|c|c|c|c|c|c}
\multicolumn{9}{c}{$\mathrm{b}$ : 有彩色ライン回帰式の定数項 $\mathrm{x}$ : 輝度比 } \\
\hline \multirow{2}{*}{ ライン } & \multicolumn{3}{|c|}{$100 \mathrm{l}$} & \multicolumn{4}{|c}{$1000 \mathrm{x} \mathrm{x}$} \\
\cline { 2 - 7 } & $\mathrm{a}_{2}$ & $\mathrm{~b}_{2}$ & $\mathrm{R}^{2}$ & $\mathrm{a}_{2}$ & $\mathrm{~b}_{2}$ & $\mathrm{R}^{2}$ \\
\hline 5R4 & 0.40 & 0.14 & 0.96 & 0.36 & 0.11 & 0.99 \\
\hline 5Y8 & 0.36 & 0.21 & 0.67 & 0.33 & 0.19 & 0.82 \\
\hline 5G5 & 0.56 & 0.01 & 1.00 & 0.41 & 0.12 & 0.97 \\
\hline 5B5 & 0.56 & 0.02 & 1.00 & 0.44 & 0.12 & 0.98 \\
\hline
\end{tabular}
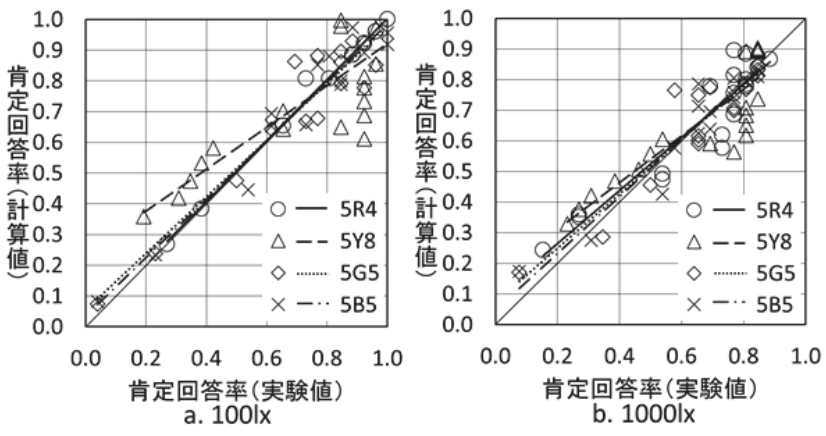

図 15 肯定回答率の実験值と計算値との関係（有彩色） 表 9 実験值と計算値の回帰式（有彩色）

\begin{tabular}{|c|c|c|c|c|c|c|}
\hline \multirow{3}{*}{ ライン } & \multicolumn{3}{|c|}{$y=a \cdot x+b$} & \multicolumn{2}{|c|}{$\mathrm{y}$ : 計算値 } & 実験値 \\
\hline & & $001 x$ & & & $0001 x$ & \\
\hline & a & $\mathrm{b}$ & $\mathrm{R}^{2}$ & a & $\mathrm{b}$ & $\mathrm{R}^{2}$ \\
\hline $5 \mathrm{R} 4$ & \begin{tabular}{|c|}
0.87 \\
\end{tabular} & 0.10 & 0.89 & 0.87 & 0.09 & 0.87 \\
\hline $5 Y 8$ & 0.68 & 0.24 & 0.69 & 0.76 & 0.16 & 0.77 \\
\hline $5 \mathrm{G} 5$ & 0.92 & 0.05 & 0.94 & 0.89 & 0.07 & 0.86 \\
\hline $5 \mathrm{~B} 5$ & 0.95 & 0.04 & \begin{tabular}{|c|}
0.95 \\
\end{tabular} & 0.93 & 0.05 & 0.92 \\
\hline
\end{tabular}

以上のことから, 照度別, 色相別に, 式 7 を用いて算出した肯定 回答率 $(80 \%$ 以下 $10 \%$ 刻夕) と, 輝度比および彩度との関係を図 16 に示す.ここで, 輝度比 1 における肯定回答率 $50 \%$ を満たすライン の彩度は, $5 \mathrm{R} 4$ は $100 \mathrm{~lx}$ で $4.2,1000 \mathrm{~lx}$ で 4.9, $5 \mathrm{Y} 8$ は $100 \mathrm{~lx}$ で 7.9 , 1000lx で 10.0, 5G5 は 100lx で 4.5, 1000lx で 4.9, 5B5 は 100lx で 4.7, 1000lx で 5.2 である. すなわち, $5 \mathrm{Y} 8$ は 7.9, 10.0 と高い が，その他は $4.2 〜 5.2$ の範囲であることが分かる.

また，実験で扱った最低彩度 2 における肯定回答率 $50 \%$ を満たす 輝度比は, 5R4 は $100 \mathrm{~lx}$ で $1.8,1000 \mathrm{~lx}$ で $2.3,5 \mathrm{Y} 8$ は $100 \mathrm{~lx}$ で 1.9 , 1000lx で 2.2, 5G5 は 100lx で 1.9, 1000lx で 2.0, 5B5 は 100lx, $10001 \mathrm{x}$ ともに 1.9 である. すなわち, 肯定回答率 $50 \%$ を満たす輝度 比は, $1.8 \sim 2.3$ の範囲である.

\section{4. 考察}

岩田ら 16) は, 弱視者を対象とした 0 1000lx 条件下の背景 (N9・ N3）と無彩色ライン（N8・N6・N4・N2）の視認性評価実験にお いて, 「眩しすぎて見にくい」の評価は, 青年健常者が, 1000 lx以 下で「眩しすぎて見にくい」と回答する者がいなかったのに対して, 弱視者では, 背景 N9 は $35 \%$, 背景 N3 は $28 \%$ となり, 眩しさによ る 10001x での視認性の低下を明らかにしている. よって, 本研究 結果で, 無彩色ライン, 有彩色ラインのいずれも, 1001x が 1000lx
よりも視認性評価が高くなったのは, 弱視者の多くが眩しさに弱い 視認特性をもつことによる影響が考察できる.

一方, 誘導ブロックと舗装材（背景）の組み合わせについて, 岩 崎ら ${ }^{17)}$ は, 輝度比 $1.5 \sim 2.5$ が, 弱視者, 晴眼者双方にとって問題 ない範囲であるとしている。 また, 国土技術研究センターによる道 路のバリアフリーガイドライン $\left.{ }^{18}\right)$ では, 輝度比 2.0 程度あることを 求めており，多くの自治体 19$)$ においてこれを目安に誘導ブロック の整備を進めている.

しかしながら, 本研究の結果, 無彩色背景における無彩色ライン は, 肯定回答率 $50 \%$ を満すためには, $1001 \mathrm{x}$ の正対比は 2.1 以上, $1000 \mathrm{~lx}$ の正対比は 2.3 以上, 負対比は 2.1 以上必要であり, この輝 度比 2.0 では, これらの条件で肯定回答率 $50 \%$ を満たさないことが 分かった。 また, 彩度 2 の有彩色ラインでは, 肯定回答率 $50 \%$ を満 すためには, 1000lx の 5R4 および $5 \mathrm{Y} 8$ は輝度比 2.3 が必要であり, 輝度比 2.0 では肯定回答率 $50 \%$ を満たさないことが分かった。

竹田ら 20) によると, 施工例の多い黄色の誘導ブロックの実測值 は 5Y8/6 であるとしている. 図 16 から，5Y8/6 で輝度比 2 の肯定 回答率は, $100 \mathrm{~lx}$ で $61.6 \%, 1000 \mathrm{~lx}$ で $54.4 \%$ であり，6 割程度の肯 定回答率であることが分かる.より高い肯定回答率を得るためには, 図 16 に従って, 目標とする肯定回答率に合った輝度比と彩度の関 係を得ることで，設計目標に従った解決策が見いだせる.
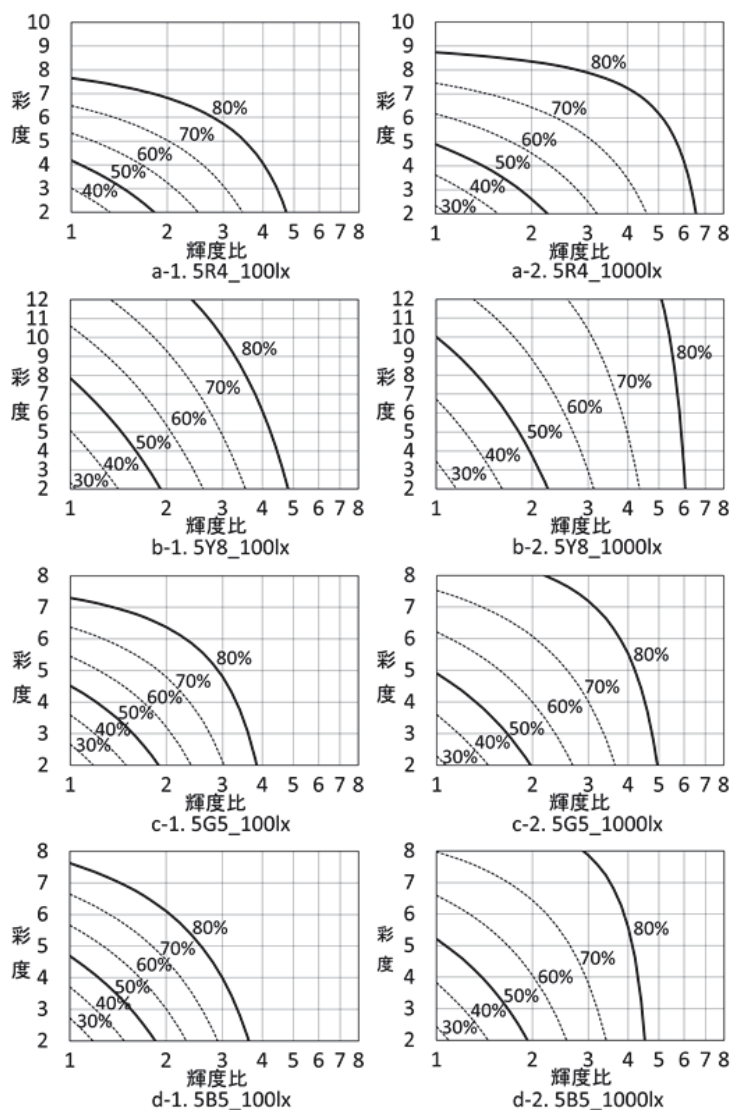

図 16 輝度比と彩度と肯定回答率の関係

\section{5. まとめ}

本研究では，弱視者を被験者とし，100lx および 1000lx の照度条 件下で, 無彩色背景（3 色）における無彩色ライン（8 色）および 有彩色ライン（35 色）の視認性の検討を行った. 得られた知見を以 下にまとめて示す. 
(1) 疾病および色覚による検討の結果, 疾病別に無彩色ライン（輝 度コントラスト）の評価が最も低かったのは網膜系であるが, 概ね 疾病間に有意差は認められなかった。また, 有彩色ラインの評価を 色覚で検討した結果, 色覚異常ありの被験者の方が概ね有意に低か った.

（2）無彩色ラインの視認性について, 輝度対比および輝度比と肯 定回答率の関係を, 戝および推定式で示した。視覚障害者誘導ブロ ックの設置の目安として輝度比 2 の数值が用いられているが, 本実 験条件下では, 肯定回答率 50\%を得る上で, 100lx の正対比では 2.11 以上, $1000 \mathrm{~lx}$ の正対比では 2.27 以上, 負対比では 2.06 以上が必要 であることが分かった。

(3) 有彩色ラインの視認性について, 彩度 4 の色相別 20 色の肯定 回答率は, 明度差の影響を受けて, 背景 N9 では $5 \mathrm{G} \sim 10 \mathrm{R}$ の低明 度色, 背景 N3 では 5YR〜 10GY の高明度色の肯定回答率が高かっ た。 また, 肯定回答率 $80 \%$ 以上のものが $100 \mathrm{~lx}$ では 30 通り, 1000lx では 17 通りあった。

（4） 5R4・5Y8・5G5・5B5 の 4 色相の有彩色ラインについて，照 度別, 背景別に肯定回答率と彩度との関係を求めた。概衫度が高 くなると肯定回答率が高くなる傾向が認められるが, 明度差が大き いものは彩度が低くても肯定回答率が高く彩度の効果は得られにく いことが分かった，その特徵を持つものとして $5 \mathrm{Y} 8$ を示した。

（5） 5R4・5Y8・5G5・5B5 の 4 色相の有彩色ラインについて，照 度別, 背景別に肯定回答率と彩度および輝度比との関係を肯定回答 率 10\%刻み（80\%以下）で図示した。この図を用いて目標とする肯 定回答率に合った輝度比と彩度の関係を得ることができる.

\section{6. おわりに}

本研究により, 弱視者を対象に無彩色背景における無彩色および 有彩色ラインの視認性を検討し, 背景とラインとの輝度比, 有彩色 ラインの彩度などと肯定回答率との関係を示した。 その結果は, 実 験室実験によるものであり，実環境では JIS 標準色票などにより明 度 $(\mathrm{V})$ を目視で測り，それを視感反射率 $(\mathrm{Y} \fallingdotseq \mathrm{V}(\mathrm{V}-1))$ に換え て反射率の比, 寸なわち輝度比を算定することにより対応すること が可能である.しかし, 実環境では個々の視環境条件に基づく利用 上の判断を加えた適正な条件を設定する必要があることを追記する.

今日, 路面は有彩色のタイルや舗装なども存在し, 今回と同様の 実験で，有彩色背景についての検討もしている 21)ので，次の機会 に報告したい, 本研究の成果が，今後の弱視者を取り巻く生活環境 の改善に寄与し,学術研究の新たな展開の一助となれば幸いである.

\section{謝 辞}

本研究のデータ収集においては, 摂南大学工学部建築学科 1997 年度卒業生の福田高志君, 西岡聡子さんの多大なる協力を得ました. また，被験者として多くの方に協力をいただきました。ここに記し て感謝申し上げます。本研究は JSPS 科研費 26289208 の助成を受 けたものです。

※本研究は，24th Session of the CIE，1999 に概要 21) を投稿して いる。
注）視力の和とは，両眼視による視力ではなく，両眼の視力を別々に測った 数值の和のことで, 視覚障害者等級を判定する際に用いられる.

\section{参考文献}

1）本田恵子, 秋山哲男, 坂口睦男：アンケートによる視覚障害者のニーズと 視覚障害者誘導ブロックの役割, 土木学会年次学術講演会講演概要集第 4 部 Vol.52, pp.80-81, 1997

2）坂口陸男，山下弘美，秋山哲夫 : 視覚障害者用誘導ブロックの設置状況と 歩道舗装について, 土木学会年次学術講演会講演概要集第 5 部 Vol.48, pp.788-789, 1993

3）佐々木隆彦，清田勝，田上博：点字ブロックが自転車利用者や歩行車の走 行挙動に及ぼす影響, 土木学会西部支部研究発表会講演概要集 Vol.2, pp.758-759, 1998

4）三上貴正，天野真二，渡会奈由香，坂井映二：点字ブロックおよびその敷 設状態の触覚的認知性に関寸る基礎的研究, 日本建築学会構造系論文集, No.528, pp.47-52, 2000.2

5）山田美紀，亀谷義浩 : 視覚障害者の螺旋スロープ昇降における空間把握に 関寸る研究，日本建築学会計画系論文集，No.707，pp.65-74，2015.1

6) 田中直人，岩田三千子 : 視覚障害者誘導ブロックに関する敷設者と利用者 の意識からみた現状と課題 - 福祉のまちづくりにおける高齢者および障 害者を考慮したサインデザインに関する研究，日本建築学会計画系論文集， 第 502 号, pp.179-186, 1997.12

7）伊藤納奈，佐川賢，岩田朋巳，三谷誠二，松下一馬：ロービジョン者を対 象とした視覚障害者誘導用ブロック等の視認性に関する調査，人間工学 41(Supplement), pp.148-149, 2005

8）坂井友香, 斉藤健治, 清田勝: 視覚障害者誘導環境のあり方について〜佐 賀市視覚障害者誘導用ブロックの利用実態と敷設の現状調査より〜，佐賀 大学理工学部集報，35-1，pp.63-77，2006.6

9）坂口陸男, 久下晴巳, 坂田耕一, 秋山哲夫 : 視覚障害者用誘導ブロックの 視認性と景観性に関寸る検討, 第 15 回交通工学研究発表会論文報告集, pp.133-136, 1995.11

10）江菩公暢，藤田晃弘，今井宏樹：視覚障害者誘導用ブロックの夜間にお ける視認性評価，土木学会年次学術講演会講演概要集第 4 部，Vol.57, pp.43-44, 2002

11）田中直人，岩田三千子：夜間歩行におけるロービジョン者の意識と街路 空間の視環境調査，日本建築学会計画系論文集，第 613 号，pp.89-94, 2007.3

12）今泉真，藤田晃弘，江齐公暢：蛍光材料を用いた視覚障害者誘導用ブロ ックの視認性評価, 土木学会年次学術講演会講演概要集第 4 部, Vol.58, pp.577-578, 2003

13）竹田恵子，川上 光彦，菊岡雅治：CG を用いた視覚障害者誘導用ブロッ クと舗装面の色彩の組み合わせに関する実験的研究, 土木計画学研究・ 論文集 $13 ， p p .957-963 ， 1996.8$

14）高井智代，石田秀輝：視覚障害者誘導用ブロックの視認性：公共空間に おける視覚障害者の歩行安全性に関する研究 その 1 , 日本建築学会計画 系論文集, 520，pp.153-158，1999.6

15）国土交通省 : 高齢者, 障害者等の円滑な移動等に配慮した建築設計標準, 2012.7

16）岩田三千子，北本裕之：弱視者の明視に関わる照度と輝度比の関係，日 本建築学会環境系論文集，第 732 号，pp.121-128，2017.2

17）岩崎聖司，坂口陸男，秋山哲男：視覚障害者誘導用舗装の現況に関する 調查例，舗装 $29-4 ， 1994$

18）（財）国土技術研究センター：増補 改訂版 道路の移動等円滑化整備ガ イドライン（道路のバリアフリー整備ガイドライン），大成出版社，2011

19）神戸市: 神戸市バリアフリー道路整備マニュアル 〜ユニバーサルデザイ ンをめざして〜 [2016 改訂版], 2016

20）竹田恵子, 川上 光彦, 菊岡雅治 : 視覚障害者誘導用ブロックと舗装面の 色彩の適切な組み合わせに関する実験的研究, 土木計画学研究・講演集 No.18(2), pp.831-834, 1995.12

21) Michico Iwata : Research on the visibility of tactile blocks for visually impaired people, 24th Session of the CIE, pp.123-125, 1999 


\title{
STUDY ON THE VISIBILITY OF CHROMATIC AND ACHROMATIC COLOR LINES FOR VISUALLY CHALLENGED PEOPLE
}

\section{Michico IWATA* and Hiroyuki KITAMOTO**}

\author{
* Prof., Dept. of Living and Environmental Design, Faculty of Science and Engineering, Setsunan Univ., Ph. D. \\ ** Visiting Assoc. Prof., Graduate School of Human Life Science, Osaka City Univ., Ph. D.
}

In this study, the authors have sought under laboratory conditions to evaluate the visibility of the targets and the backgrounds consisting of 129 color combinations under two illuminance conditions. The results of our research are as follows:

(1) The visibility of chromatic and achromatic color lines for visually challenged subjects suffering from defective eye conditions, such as retinal and or ophthalmological diseases, which included defective colour vision, were analyzed. Findings showed that subjects with diseases of the retina scored lowest for achromatic color lines. However, no significant differences were recognized between the groups suffering from defective eye conditions. Additionally, subjects with defective color vision showed low scores for the chromatic color lines.

(2) The affirmation visibility rates of the achromatic color lines are represented by two graphs which show estimated formulas using luminance contrast or luminance ratio. Thus, a luminance ratio of 2 adhered to guidelines which indicated the leading road line for the almost half of the visually challenged subjects to be inadequate.

(3) The affirmation visibility rates of the chromatic colour lines were greatly affected by the luminosity difference between the lines and the backgrounds.

(4) The relationship between the affirmation visibility rates and chroma of 5R4, 5Y8, 5G5, 5B5 chromatic colour lines showed that as chroma increased, the affirmation visibility rate also increased. When the luminosity difference between these lines and the backgrounds increased, the effectiveness of the chroma did not impact upon the affirmation visibility rates. The 5 Y8 line shows this characteristic especially.

(5) The affirmation visibility rates of the 5R4, 5Y8, 5G5, 5B5 chromatic color lines are shown in the graphs, each with a rate of $10 \%$. The affirmation visibility rates of chromatic color lines depend on the luminance ratio and the chroma is clearly depicted by these figures. 